九州大学学術情報リポジトリ

Kyushu University Institutional Repository

\title{
Bacteriophages of Bacillus natto : 1. Some characteristics of phage NP-1
}

Yoshimoto, Akihiro

Laboratory of Applied Microbiology, Department of Agricultural Chemistry, Kyushu University

Hongo, Motoyoshi

Laboratory of Applied Microbiology, Department of Agricultural Chemistry, Kyushu University

https://doi.org/10.5109/22801

出版情報：九州大学大学院農学研究院紀要. 16 (2)，pp.141-158，1970-07. Kyushu University バージョン：

権利関係 : 
Journal of the Faculty of Agriculture, Kyushu University, Vol. 16, No. 2 July 31,1970

\section{Bacteriophages of Bacillus natto}

1. Some characteristics of phage NP.1

\section{Akihiro YOSHIMOTO' ${ }^{1}$ and Motoyoshi HONGO}

Bacillus subtilis phages were first reported by Fukuda ${ }^{10)}$ and subsequently by Kitahara et al. $^{13)}$ and Watanabe et al. ${ }^{31}$ as phage active against amylase-producing strains of $B$. subtilis. Kinoshita et al.12) also isolated a subtilis phage from seweage. Afterward, as a result of discovery of DNA-mediated transformation, many phages which infected a transformable Marburg strain of $B$. subtilis have been actively isolated for the investigation of genetic phenomena. A series of phages SP were isolated by Romig et al. ${ }^{23}$ and transducing phages were isolated by Takagi, ${ }^{26)}$ Takahashi ${ }^{27}$ and Thorne et al. ${ }^{31}$

Recently, Brodetsky et al.5) studied on various properties of their subtilis phages, set them apart from some other subtilis phages and distinguished them from each other. Subtilis phages have the notable characteristics that some of them contain unusual base such as uracil or hydroxymethyl uracil in their $\mathrm{DNA}^{11.24 .30)}$ and most of the temperate phages can transduce various makers. ${ }^{26.27 .31)}$ 'Therefore, with Bacillus natto phage, it would be also expected to find out such characteristics as observed with subtilis phages. A virulent phage of $B$. natto was isolated from abnormally fermented "natto" and characterized by Fujii et al."

This paper presents some characteristics of a temperate phage which was isolated from abnormal "natto" forming no mucilage.

\section{Materials and methods}

\section{Bacterial strains}

Strain Takahashi No. 1 and No. 3 of Bacillus natto were obtained from Prof. H. Fujii, Fukuoka Women's University. Strain No. 3 was used as a host bacterium. B. subtilis var. amyloliquefaciens was obtained from

1) Laboratory of Applied Microbiology, Department of Agricultural Chemistry, Kyushu University, Fukuoka, Japan 
Prof. K. Watanabe, Fukuoka University and other Bacillus strains were obtained from Prof. Y. Ikeda, Tokyo University. Escherichia coli strain B was obtained from Prof. H. Endo, Kyushu University.

\section{Phages}

A phage of $B$. natto was isolated from abnormal "natto" forming no mucilage by usual technique and purified twice by single plaque isolation. This phage was designated NP-1. Stock phages were prepared by centrifuging the phage lysate at $8000 \mathrm{rpm}$ for $15 \mathrm{~min}$, and the supernatant fluid was filtered throughout seizfilter and stored at $4^{\circ} \mathrm{C}$. The phage stock with titers of $10^{\circ}$ to $10^{10}$ plaque-forming units (PFU) per $\mathrm{ml}$ was routinely obtained. Phage suspension having high titer was prepared by suspending the phages collected by a differential centrifugation in buffered saline $(0.1 \mathrm{M} \mathrm{NaCl}$ and $0.005 \mathrm{M} \mathrm{MgSO}$ in $0.06 \mathrm{M}$ phosphate buffer, $\mathrm{pH}$ 7.2).

Coli phages $T_{2}, T_{3}$ and $T_{5}$ were obtaind Prof. H. Endo. Phages were assayed according to the double layer method by Adams." Physiological saline or buffered saline was used for the dilution of phages.

\section{Media}

PY medium used for the propagation of Bacillus strains and phage $\mathrm{NP}-1$ contained $1 \mathrm{~g}$ glucose, $10 \mathrm{~g}$ peptone, $1 \mathrm{~g}$ yeast extract, $0.02 \mathrm{~g} \mathrm{CaCl}_{2}$. $2 \mathrm{H}_{2} \mathrm{O}, 0.5 \mathrm{~g} \mathrm{MgSO}_{4} .7 \mathrm{H}_{2} \mathrm{O}, 0.05 \mathrm{~g} \mathrm{~K}_{2} \mathrm{HPO}_{4}$ and $3 \mathrm{~g} \mathrm{NaCl}$ in $1,000 \mathrm{ml}$ of distilled water, pH 7.0. For the propagation of $E$. coli strain B and coli phages, PY medium from which yeast extract was removed was used.

\section{Preparation of antiphage serum}

The antiserum of phage NP-1 was prepared according to the method of Adams." The obtained antiserum had a neutralization rate constant (K) of about $60 \mathrm{~min}^{-1}$.

\section{Host range}

Host range was determined by spot test; overnight cultures of various Bacillus strains grown in PY medium were overlaid on the basal layers, and one drop of phage stock was spotted on the plates. The plates were incubated at $37^{\circ} \mathrm{C}$ overnight, and the resulting lysis area was examined.

\section{Adsorption}

For the determination of adsorption rate $0.1 \mathrm{ml}$ of phage suspension $\left(10^{10} \mathrm{PFU} / \mathrm{ml}\right)$ was added to $10 \mathrm{ml}$ of $4-\mathrm{hr}$ incubated host culture. The mixture was shaken at $37^{\circ} \mathrm{C}$, and $0.1 \mathrm{ml}$ was removed at various time 
intervals and was immediately diluted $1: 100$ with chilled saline. After centrifugation, the supernatant fluids was assayed for unadsorbed phages. Adsorption rate (K) was calculated according to Adams."

Effect of various metal ions on the adsorption was tested in Tris buffer $(0.01 \mathrm{M}, \mathrm{pH} 7.0)$ containing each metal ion; host culture $\left(4 \times 10^{8}\right.$ viable cells $/ \mathrm{ml}$ ) was centrifuged and the cells were suspended in the original volume of Tris buffer containing $0.01 \mathrm{M}$ EDTA. The cell suspension was stood for 5 min with occasionally shaking. After centrifugation, the cells were washed twice with Tris buffer in the cold and finally suspended in the original volume of the same buffer containing each metal ion. To each $5 \mathrm{ml}$ of the cell suspensions was added $0.1 \mathrm{ml}$ of phage suspension $\left(5 \times 10^{5} \mathrm{PFU} / \mathrm{ml}\right)$, and the mixtures were incubated at $37^{\circ} \mathrm{C}$ for $10 \mathrm{~min}$ with shaking. After centrifugation, the supernatant fluids were assayed for unadsorbed phages.

\section{Thermal inactivation}

For the determination of thermal inactivation, the tubes containing $4.5 \mathrm{ml}$ of buffered saline were maintained at various temperatures, and $0.5 \mathrm{ml}$ of phage suspension $\left(10^{10} \mathrm{PFU} / \mathrm{ml}\right)$ was then added to them and throughly mixed. At various time intervals $1 \mathrm{ml}$ was removed and added to $9 \mathrm{ml}$ of chilled saline. Phage survivals were assayed after appropriate dilution.

\section{UV inactivation}

Ten $\mathrm{ml}$ of buffered saline containining phages $\left(10^{9} \mathrm{PFU} / \mathrm{ml}\right)$ in a petri dish ( $9 \mathrm{~cm}$ in diameter) was irradiated at a distance of $40 \mathrm{~cm}$ under 15-W Toshiba germicidal lamp GL-15, while the dish was gently swirled by hand. Samples taken at various time intervals were diluted and assayed for phage survivals.

\section{Preparation on phage DNA}

Thirty shaking flasks containing $100 \mathrm{ml}$ of PY medium were inoculated with $1 \mathrm{ml}$ of overnight culture and shaken at $37^{\circ} \mathrm{C}$ for $3 \mathrm{hr}$. The cultures were infected with phage NP-1 at a multiplicity of about 3 and incubated further for $4 \mathrm{hr}$. Although the cultures were not completely lysed by this time, they were centrifuged at $9,000 \mathrm{rpm}$ for 15 min. The obtained supernatant fiuid $(2,800 \mathrm{ml})$ contained phages of $10^{10}$ $\mathrm{PFU} / \mathrm{ml}$. Phages were collected from the supernatant fluid by ultracentrifuge at $35,000 \times \mathrm{g}$ for $1 \mathrm{hr}$. The phages were suspended in $60 \mathrm{ml}$ of buffered saline and again centrifuged at $9,000 \mathrm{rpm}$ for $15 \mathrm{~min}$. To the phage suspension were added RNase and DNase (Shigma Co.) to give a final concentration of each $20 \mu \mathrm{g} / \mathrm{ml}$. The suspension was incubated at $37^{\circ} \mathrm{C}$ for $30 \mathrm{~min}$. The phages were then purified by two 
cycles of differential centrifugation. The phage pellet was suspended in $20 \mathrm{ml}$ of buffered saline. Phage DNA was extracted according to the method by Mandel et al. ${ }^{17}$ To the phage suspension was added an equal volume of phenol saturated with water and the mixture in a glass-stoppered flask was shaken by hand for $5 \mathrm{~min}$. The resulting emulsion was separated by centrifugation at $4,000 \mathrm{rpm}$ for $10 \mathrm{~min}$. The aqueous layer was removed by pipetting out. This procedure was.repeated three times. The obtained aqueous fraction made to be free from phenol by extracting three times with ether. Ether was removed under reduced pressure at $30^{\circ} \mathrm{C}$. The aqueous solution was then dialyzed against standard saline citrate $(1.5 \mathrm{M} \mathrm{NaCl}$ in $0.15 \mathrm{M}$ citrate buffer, PH 7.2). DNA was estimated by the diphenyl amine method.6) This preparation contained $680 \mu \mathrm{g} / \mathrm{ml}$ of DNA and was still contaminated with $1.5 \% \mathrm{RNA}$ and $1 \%$ protein.

\section{Base composition of phage DNA}

Phage DNA was precipitated from the DNA solution with two volumes of $95 \%$ ethanol and dried in vacuo. The DNA was hydrolyzed with formic acid (over $98 \%$ ) in a sealed glass tube at $175^{\circ} \mathrm{C}$ for $30 \mathrm{~min}$. The hydrolyzed DNA solution was evaporated to dryness under reduced pressure. To the residue was added $1 \mathrm{ml}$ of $1 \mathrm{~N} \mathrm{HCl}$. The solution was submitted to descending paper chromatography, using Whatman No. 1 filter paper and a solvent system of isopropanol-concd. HClwater $(15: 17: 18) .{ }^{35}$ ) The spots on the chromatogram were detected under a Manasulu light (Manasulu Chemical Industries). The detected area were cut out, and the base in each area was eluted with $0.1 \mathrm{~N}$ $\mathrm{HCl}$. The bases were determined spectrophotometrically with a Hi:achi spectrophotometer (model EPU 2A) with use of the following molecular extinction coefficients at $260 \mathrm{~m} \mu^{33)}$ : adenine, 12,700; guanine, 8,100 ; cytosine, 6,200 ; thymine, 7,400 .

\section{Determination of $\mathrm{Tm}$ of phage DNA}

Tm value was determined by the method according to Marmur and Doty ${ }^{18)}$ with modification. The glass-stoppered tubes containing about $100 \mu \mathrm{g}$ of DNA in $5 \mathrm{ml}$ of 10 -fold diluted saline citrate were heated at a rising rate of $1^{\circ} \mathrm{C}$ up per $2 \mathrm{~min}$ after the temperature was somewhat rapidly increased until $70^{\circ} \mathrm{C}$. One tube was taken at about $2^{\circ} \mathrm{C}$ intervals, immediately chilled in ice water and the absorbance at $260 \mathrm{~m} \mu$ of the sample was measured with a Hitachi spectrophotometer. Guanine plus cytosine contents were calculated according to Marmur and Doty's equation: ${ }^{18}$

Per cent $\mathrm{G}+\mathrm{C}=(\mathrm{Tm}-69.3) / 0.41$ 


\section{Amino acid analysis of phage protein}

Phage NP-1cl, a clear plaque mutant, was harvested from $2,000 \mathrm{ml}$ of the phage lysate which contained about $8 \times 10^{9} \mathrm{PFU} / \mathrm{ml}$. The phages were washed by two cycles of differential centrifugation as described above. Phage pellet was suspended in M/80 Tris buffer ( $\mathrm{pH} 7,2$ ) containing $10^{-3} \mathrm{M} \mathrm{MgSO}$, and applied to DEAE-cellulose column chromatography. The column $(3.0 \times 20 \mathrm{~cm})$ was equilibrated with the same buffer. After the phage solution $\left(8 \times 10^{10} \mathrm{PFU} / \mathrm{ml}, 20 \mathrm{ml}\right)$ was placed and then $30 \mathrm{ml}$ of the same buffer was poured, the phage was eluted with a stepwise of $\mathrm{NaCl}$ concentration in the buffer. The fractions containing phage were collected and centrifuged at $48,000 \times \mathrm{g}$ for one hour. After one cycle of differential centrifugation, the phage pellet was taken into a small glass tube and $1.5 \mathrm{ml}$ of $6 \mathrm{~N} \mathrm{HCl}$ was added. The tube was sealed and heated for $20 \mathrm{hr}$ in boiling water. The acid hydrolysate was repeatedly evaporated to remove $\mathrm{HCl}$ in adding a small volume of water. The residue was examined for amino acids by autoamino acid analyzer (Hitachi).

\section{Lysogeny}

To determine the frequency of lysogenization 4-hr incubated culture $\left(2 \times 10^{8}\right.$ viable cells $\left./ \mathrm{ml}\right)$ was infected with phage at various multiplicities at $37^{\circ} \mathrm{C}$. After $5-\mathrm{min}$ adsorption the culture was treated with antiserum (1:50) for $10 \mathrm{~min}$. The culture was diluted appropriately with saline and spreaded on PY agar plates. After the plates were incubated overnight, the resulting colonies were picked out on bouillon agar slant and transferred successively three times on the new slants. The last slant culture were tested for the phage prducibility and resistance.

\section{Results and discussion}

\section{Stability}

Phage lysate did not almost decrease in the viability for one month at $4^{\circ} \mathrm{C}$. As shown in Table 1 , the phage was considerably inactivated in the various concentration of phosphate buffer except for $0.01 \mathrm{M}$. The addition of $0.01 \mathrm{M}$ divalent cations to the buffer stabilized the phage. However, $\mathrm{Cu}^{++}$and $\mathrm{Zn}^{++}$had no stabilizing effect. Some other solutions were also examined. The phage was stable in saline citrate buffer, buffered saline, physiological saline and Tris buffer. Chloroform inactivated the phage. Effect of $\mathrm{pH}$ on the phage stability was examined in the various $\mathrm{pH}$ of PY medium. The result is shown in Fig. I. 
Table 1. Stability of phage in various buffer solutions.

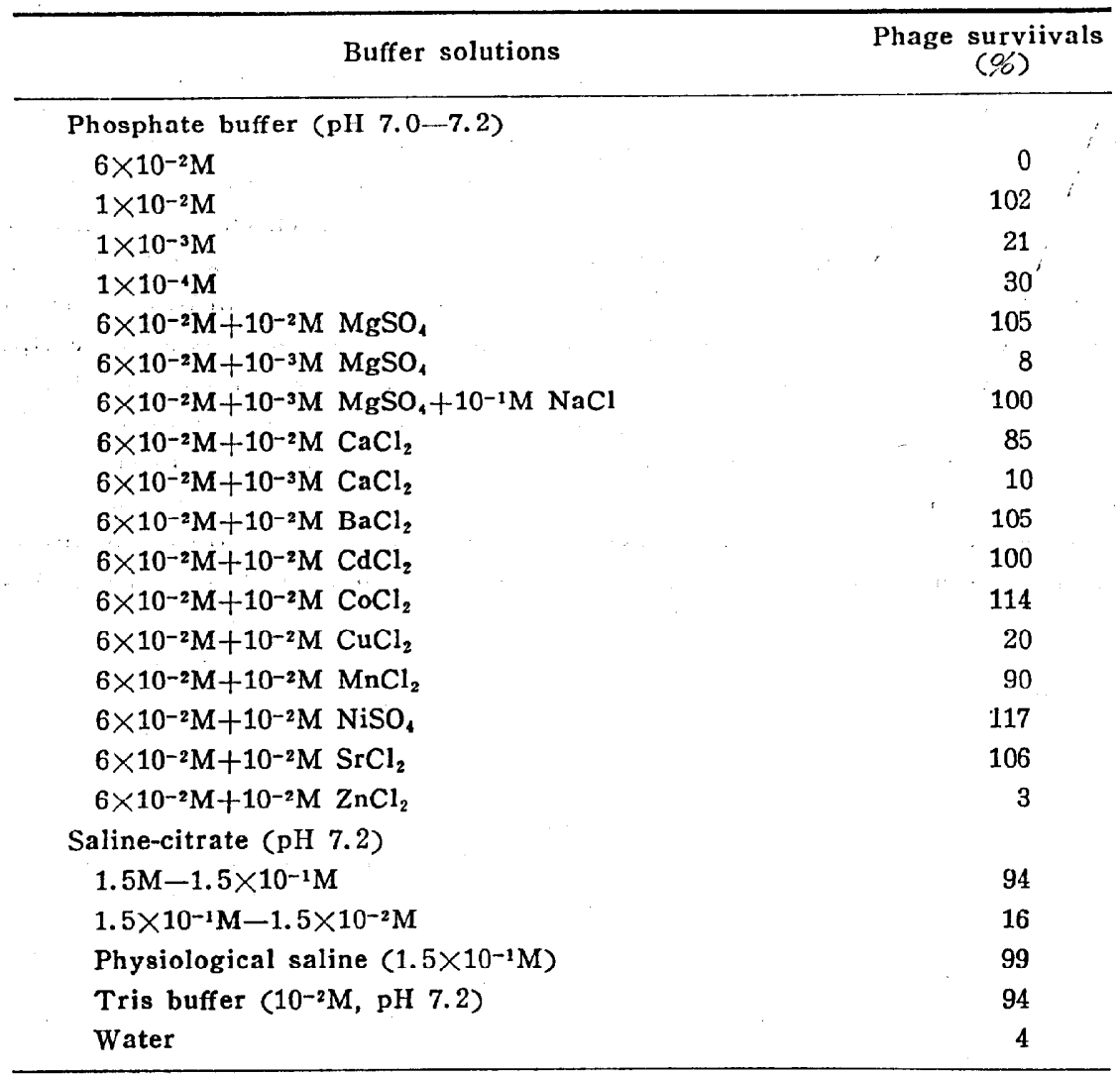

Phage suspensions were incubated at $37^{\circ} \mathrm{C}$ for $2 \mathrm{hr}$.

\section{Phage and plaque morphology}

Electromicroscopic photograph of the phage is shown in Fig. 2a. The phage had a regular six-sided head and a long noncontractile tail with its terminal appendage. The head diameter was about $600 \times 600$ $A^{\circ}$. The tail was about $80 \times 1,800 A^{\circ}$ in size and had a forked tip. It was also mostly observed as a crooked form. The empty phage with its transparent had a hollow tail exhibiting the capsomer structure more clearly (Fig. 2b).

The typical plaques of phage NP-1 and its clear plaque mutant, NP-1 $\mathrm{cl}$, are shown in Fig. 3. NP-1 formed a turbid plaque of 1.5 to $3 \mathrm{~mm}$ in a diameter with peripherical ring. NP-1 assay plate contained usually some smaller plaques $(0.25$ to $0.5 \mathrm{~mm})$ and a clear plaque at a rate of 


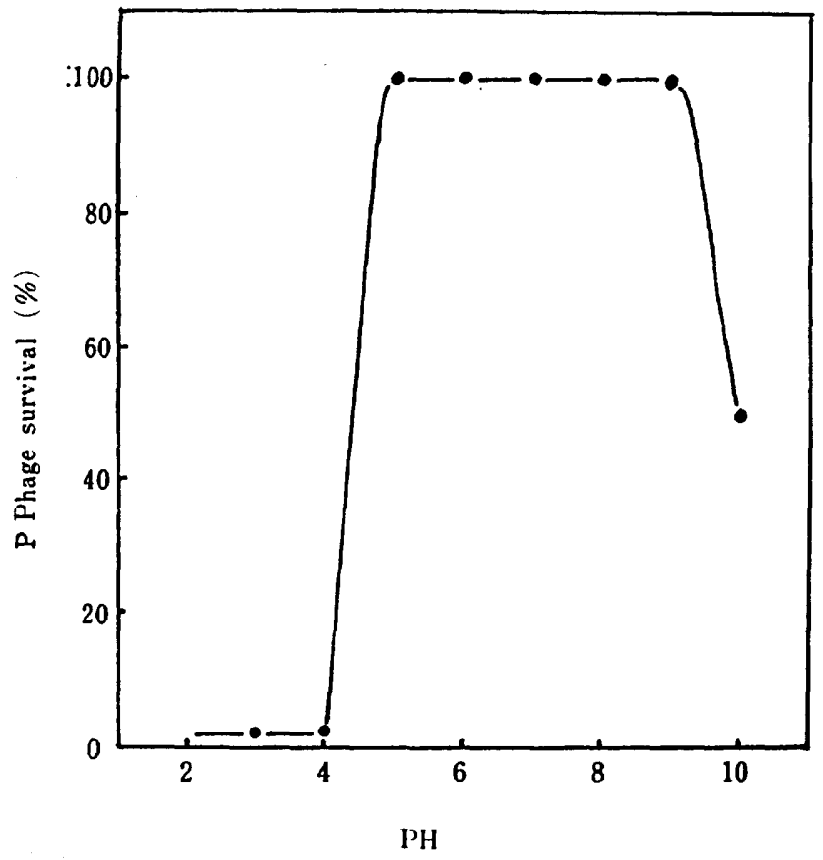

Fig. 1. pH stability of phage NP-1. Incubation: $1 \mathrm{hr}$ at $37^{\circ} \mathrm{C}$

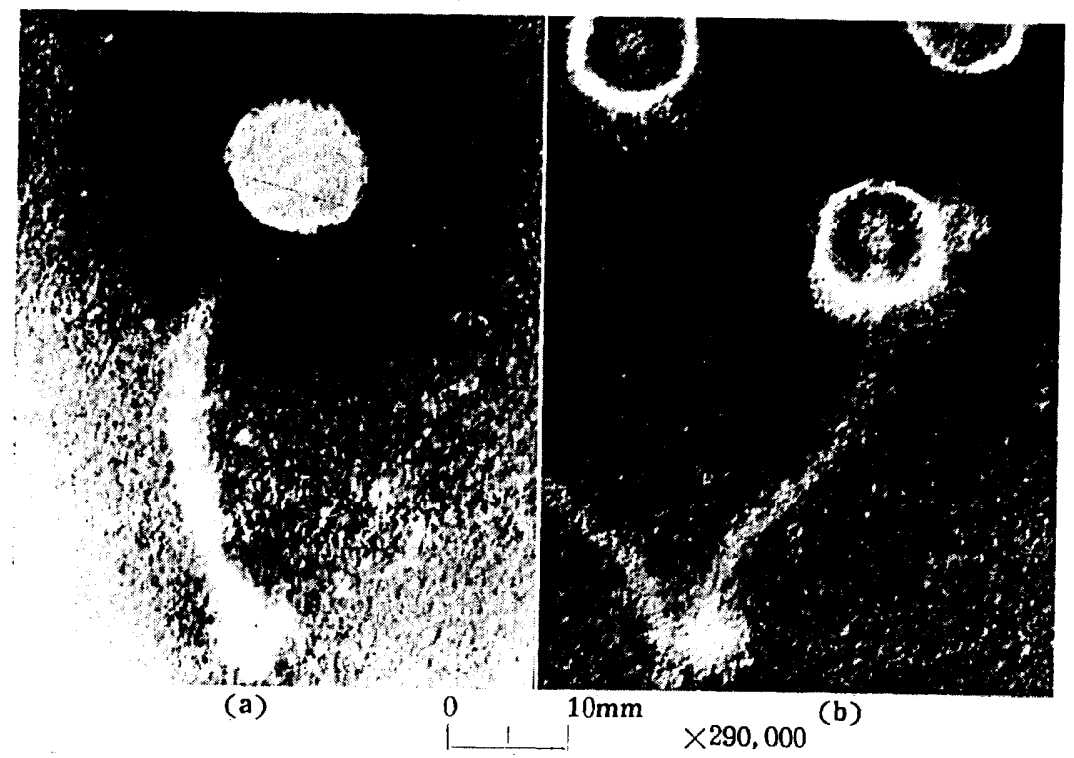

Fig. 2. Morphology of phage NP-1. 


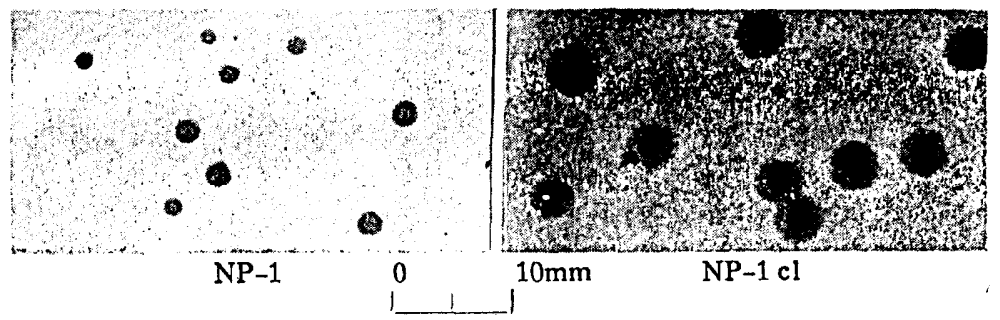

Fig. 3. Plaques of phage NP-1 and NP-1 cl.

about one per 1000 plaques. NP-1 cl formed more or less larger plaque than NP-1. Both plaques were surrounded by halo with a width of about $1.5 \mathrm{~mm}$. Halo formation was observed with Bacillus megaterium phage, ${ }^{19)}$ coli phage $\mathrm{T}_{2}{ }^{3.14}$ and Staphylococcus phage. ${ }^{22)}$ Brodetsky et al. ${ }^{51}$ also described that their subtilis phages formed halo.

\section{Host range}

Host range is shown in table 2. The phage was susceptible to $B$. natto, but not to any other Bacillus strains tested.

Table 2. Host range.

\begin{tabular}{llc}
\hline \multicolumn{1}{c}{ Organisms } & \multicolumn{1}{c}{ Strains } & $\begin{array}{c}\text { Susceptibility } \\
\text { to phage }\end{array}$ \\
\hline Bacillus subtilis & Marburg, wild & - \\
Bacillus subtilis & Marburg, W 23 & - \\
Bacillus subtilis & IAM 1523 (K) & - \\
Bacillus subtilis & amyloliquef aciens Fukumoto, K 49 & - \\
Bacillus natto & Takahashi No. 1 & + \\
Bacillus natto & Takahashi No. 3 & + \\
Bacillus megaterium & 203 & - \\
Bacillus megaterium & 899 & - \\
Bacillus megaterium & IAM 1030 & - \\
Bacillus megaterium & IAM 1032 & - \\
Bacillus cereus & IAM 1029 & - \\
Bacillus cereus & IAM 1072 & - \\
Bacillus cereus & IAM 1229 & - \\
Bacillus circulans & IAM 1112 & - \\
Bacillus circulans & IAM 1140 & - \\
Bacillus polymyxa & IAM 1189 & - \\
Bacillus macerans & IAM 1227 & - \\
Bacillus bervis & IAM 1031 & - \\
\hline
\end{tabular}




\section{Adsorption}

The phage was adsorbed on host bacteria at a rate of about $95 \%$ in $5 \mathrm{~min}$. Adsorption rate constant $(\mathrm{K})$ was $6 \times 10^{-9} \mathrm{ml} / \mathrm{min}$. The bacteria killed over $99 \%$, which were obtained by heating at $80^{\circ} \mathrm{C}$ for $10 \mathrm{~min}$, also adsorbed about $80 \%$ of input phage in $10 \mathrm{~min}$. Table 3 shows the effect of various metal ions on the adsorption. The phage did not adsorbed to the bacteria suspended in Tris buffer without metal ion, but the addition of metal ion $\left(\mathrm{Mg}^{++}, \mathrm{Ca}^{++}, \mathrm{Mn}^{++}, \mathrm{Ni}^{++}, \mathrm{Co}^{++}, \mathrm{Na}^{+}\right.$ and $\mathrm{K}^{+}$) to the bacterial suspension allowed to adsorb the phage.

Table. 3 Effect of various metal ions on adsorption of phage NP-1.

\begin{tabular}{lccc}
\hline \multirow{2}{*}{ Metal ion } & \multicolumn{3}{c}{ Concentration } \\
\cline { 2 - 4 } & $10^{-1} \mathrm{M}$ & $10^{-2} \mathrm{M}$ & $10^{-3} \mathrm{M}$ \\
\hline & & adsorption $\%$ & \\
$\mathrm{Mg}^{++}$ & - & 98.2 & 94.0 \\
$\mathrm{Ca}^{++}$ & - & 98.0 & 86.5 \\
$\mathrm{Mn}^{++}$ & - & 97.7 & 83.3 \\
$\mathrm{Ni}^{++}$ & - & 98.9 & 95.0 \\
$\mathrm{Co}^{++}$ & - & 98.8 & 96.5 \\
$\mathrm{Na}^{+}$ & 99.2 & 95.0 & 58.0 \\
$\mathrm{~K}^{+}$ & - & 96.4 & 52.4 \\
None & & 4.0 & \\
\hline
\end{tabular}

\section{Growth characteristics}

One-step growth experiments were carried out according to the method of Adams, ${ }^{12}$ and latent periods and burst sizes were determined. Phage NP-1 had a burst size of 40 to 60 and NP-1cl had that of 80 to 120 , but these values varied from experiment to experiment. Typical patterns were show in Fig. 4. Both the latent periods were about $40 \mathrm{~min}$.

Table 4 shows the effect of divalent cation on the phage propagation. A high concentration of $\mathrm{Mg}^{++}(0.01 \mathrm{M})$, which was not necessarily required for the phage adsorption and the bacterial growth, was indispensable for the optimum propagation of the phage. The poor production at a low concentration of $\mathrm{Mg}^{++}$may be attributable to both the smaller burst size and the abortive infection. Whereas, $\mathrm{Ca}^{++}$was not effective although it is generally essential for the propagation of many kinds of phage. $\mathrm{Mn}^{++}, \mathrm{Ni}^{++}$and $\mathrm{Co}^{++}$also had no effect. 


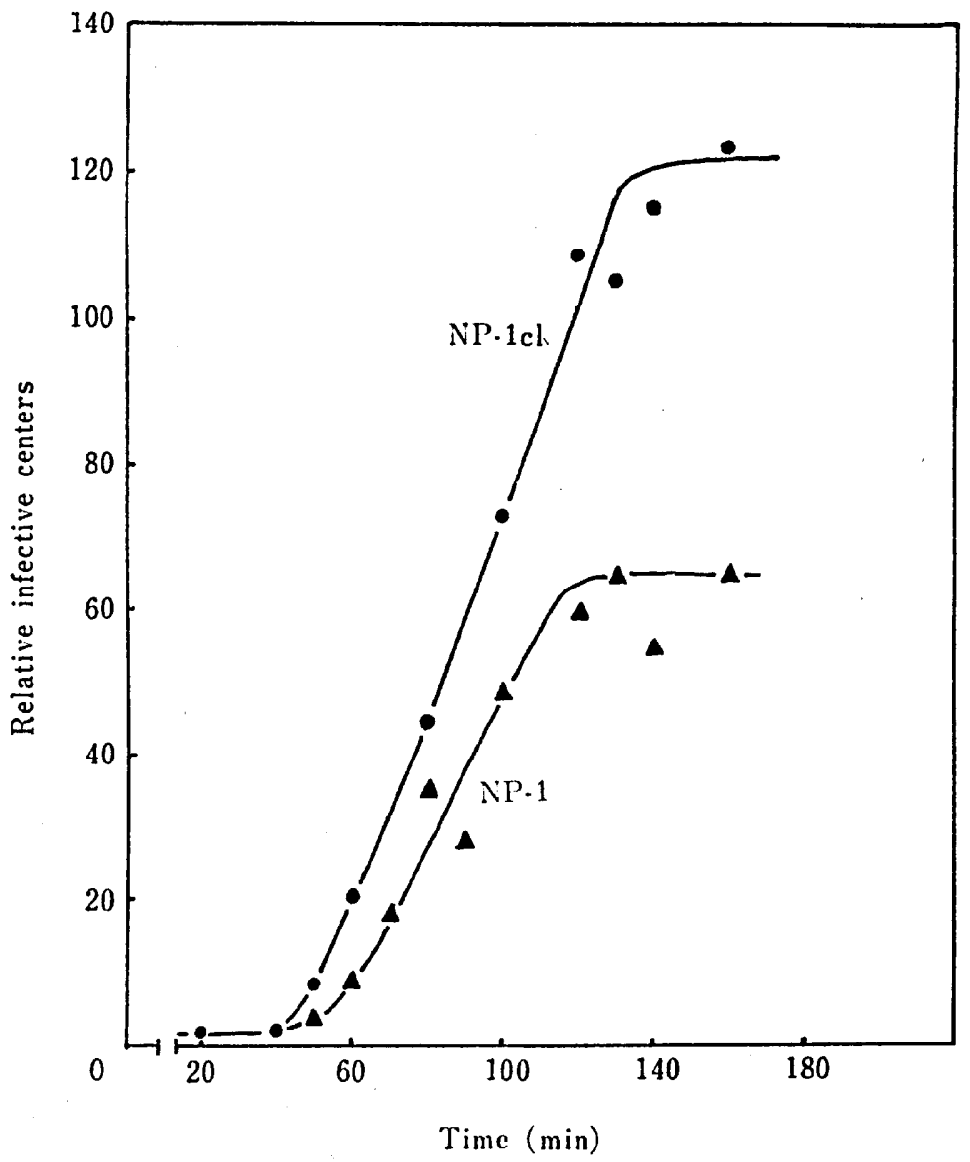

Fig. 4. One-step growth curves of phage NP-1 and NP-1cl.

Table 4. Effect of $\mathrm{Mg}^{++}$and some other divalent cations on phage NP-cl propagation.

\begin{tabular}{cccc}
\hline Metal ion added & $\begin{array}{c}\text { Time required for } \\
\text { lysis }(\mathrm{hr})\end{array}$ & Final pH & $\begin{array}{c}\text { Phage } \\
(\mathrm{PFU} / \mathrm{ml})\end{array}$ \\
\hline $\mathrm{Mg}^{++} 5 \times 10^{-2}$ & 2.5 & 5.4 & $1.2 \times 10^{10}$ \\
$\mathrm{Mg}^{++} 2 \times 10^{-2}$ & 3.5 & 5.4 & $2.3 \times 10^{10}$ \\
$\mathrm{Mg}^{++} 1 \times 10^{-2}$ & 3.5 & 5.8 & $3.0 \times 10^{10}$ \\
$\mathrm{Mg}^{++} 5 \times 10^{-3}$ & 3.5 & 6.0 & $2.6 \times 10^{10}$ \\
$\mathrm{Mg}^{++} 2 \times 10^{-3}$ & 4.0 & 7.0 & $6.0 \times 10^{9}$ \\
$\mathrm{Mg}^{++} 1 \times 10^{-3}$ & 4.0 & 5.8 & $2.0 \times 10^{9}$ \\
$\mathrm{Mg}^{++} 1 \times 10^{-4}$ & nonlysis & 5.8 & $1.0 \times 10^{8}$
\end{tabular}




\begin{tabular}{cccc}
\hline $\begin{array}{c}\text { Metal ion added } \\
(\mathrm{M})\end{array}$ & $\begin{array}{c}\text { Time required for } \\
\text { lysis (hr) }\end{array}$ & Final pH & $\begin{array}{c}\text { Phage } \\
(\mathrm{PFU} / \mathrm{ml})\end{array}$ \\
\hline $\mathrm{Mg}^{++} 1 \times 10^{-3}$ supplimented \\
with $\mathrm{Ca}^{++1} \times 10^{-2}$ & 4.0 & 6.8 & $9.0 \times 10^{8}$ \\
" $\mathrm{Ca}^{++5 \times 10^{-3}}$ & 4.0 & 6.0 & $1.0 \times 10^{9}$ \\
" $\mathrm{Ca}^{++1} \times 10^{-3}$ & 4.0 & 5.8 & $2.0 \times 10^{9}$ \\
" $\mathrm{Mn}^{++2 \times 10^{-3}}$ & 4.0 & 5.8 & $1.0 \times 10^{9}$ \\
" $\mathrm{Ni}^{++2 \times 10^{-3}}$ & 4.0 & 5.8 & $8.5 \times 10^{8}$ \\
\hline $\mathrm{Co}^{++2} \times 10^{-3}$ & 4.0 & 6.0 & $9.5 \times 10^{8}$ \\
\hline
\end{tabular}

Host bacteria were grown in PY medium containing the indicated metal ion. When the cultures reached to 0.5 at OD 660 (about $2 \times 10^{8}$ viable cells $/ \mathrm{ml}$ ), they were infected with phage at a multiplicity of 3 and incubated for $4.5 \mathrm{hr}$.

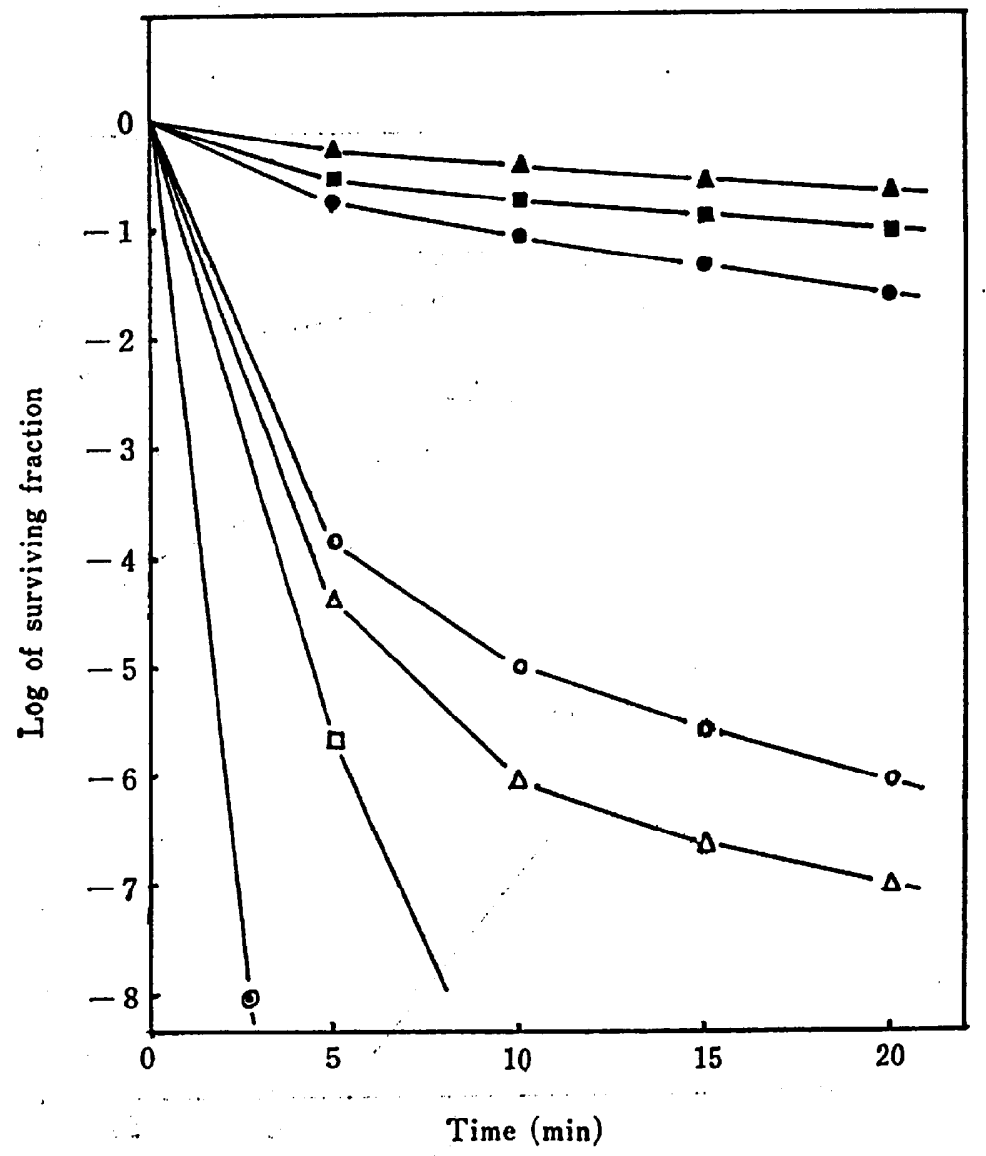

Fig. 5. Thermal inactivation of phage NP-1.

$\mathrm{NP}-1: 50^{\circ} \mathrm{C}(\mathrm{O}), 60^{\circ} \mathrm{C}(\mathrm{O}), 65^{\circ} \mathrm{C}(\triangle), 70^{\circ} \mathrm{C}(\square), 80^{\circ} \mathrm{C}(\odot)$

$\mathrm{T}_{2}: 65^{\circ} \mathrm{C}(\square) ; \mathrm{T}_{5}: 65^{\circ} \mathrm{C}(\Delta)$. 


\section{Thermal inactivation}

The phage was inactivated at $50^{\circ} \mathrm{C}$ and drastically at the temperature more than $60^{\circ} \mathrm{C}$ as shown in Fig. 5. Phage NP-1 was more sensitive to temperature than coli phage $T_{2}$ and $T_{5}$.

\section{UV inactivation}

The inactivation of phage by UV irradiation is shown in Fig. 6. The phage was strongly resistant to UV as compared with phage $T_{2}$ and $T_{3}$. The UV-inactivationcurve of NP-1 resembled that of phage SP 8.5) Okubo et al..$^{20}$ and Mahler ${ }^{16)}$ described phage SPO 2 and SP 3 to be similarly very resistant to UV, and they established that the UV resistance was attributable to the host cell reactivation ${ }^{10)}$ by which UVdamaged phage DNA was repaired in the dark. The UV resistance of phage NP.1 may be dependent on the host cell reactivation.

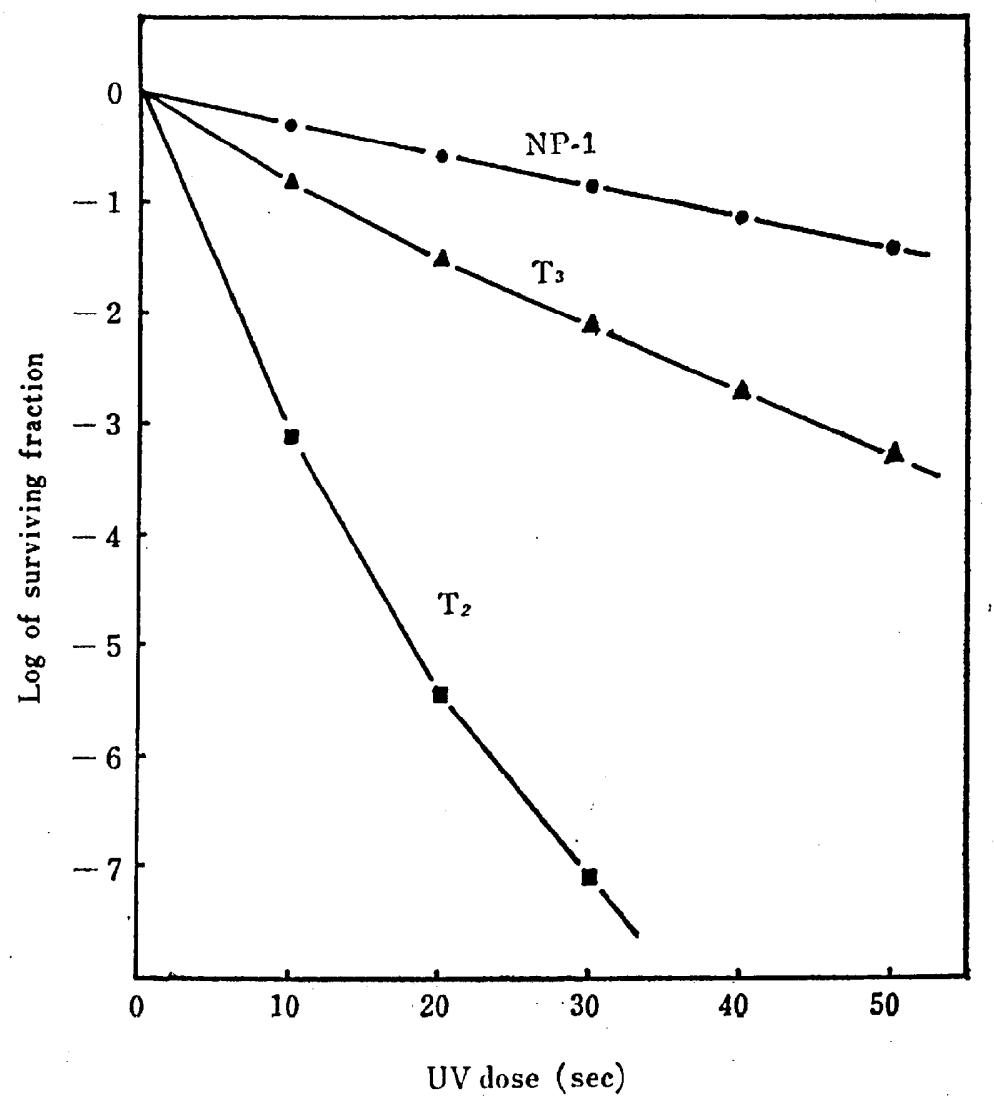

Fig. 6. Ultraviolet inactivation of phage NP-1. 


\section{Base composition of phage DNA}

The base composition of phage DNA is shown in Table 5. The DNA contained no unusual base. The molar ratio of the bases was 1.00 : $0.69: 0.71: 1.02$ with respect to adenine, guanine, cytosine and thymine in this order. Therefore, guanine plus cytosine contents were $40.9 \%$. The contents were also estimated to give $41.9 \%$ from thermal denaturation temperature ( $\mathrm{Tm}$ ) of the DNA. The denaturation curve is shown in Fig. 7.

Table 5. Base composition of phage DNA.

\begin{tabular}{lccc}
\hline Analytical methods & Bases & Molar ratio & G+C contents \\
\hline \multirow{3}{*}{ Acid hydrolysis } & Adenine & 1.00 & \\
& Guanine & 0.69 & \\
& Cytosine & 0.70 & $40.9 \%$ \\
Tm & Thymine & 1.01 & \\
& & $\left(85.6^{\circ} \mathrm{C}\right)$ & $41.9 \%$ \\
\hline
\end{tabular}

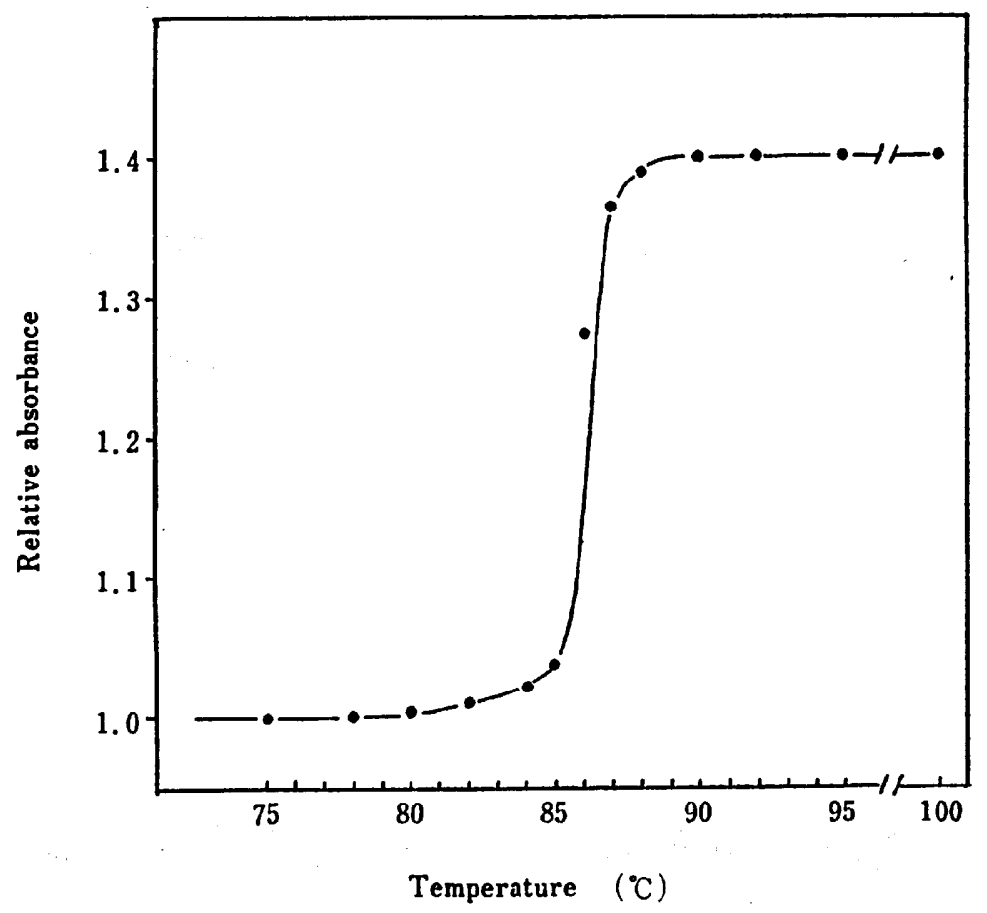

Fig. 7. Thermal denaturation of phage NP-1 DNA. 


\section{Amino acid composition of phage protein}

As shown in Fig. 8, phage NP-1 cl was purified with high recovery by column chromatography. Table 6 shows the results of amino acid analysis of the purified phage. The amino acid composition of the phage was similar to those of coli phages, ${ }^{7.21)}$ expect that aspartic acid, glutamic acid, glycine and threonine were somewhat at a high level and arginine, histidine, lysine and methionine at a slightly low level.

Table 6. Amino acid composition of phage NP-1 cl.

\begin{tabular}{lcc}
\hline \multicolumn{1}{c}{ Amino acids } & $\begin{array}{c}\text { NP-1 cl* } \\
(\%)\end{array}$ & $\begin{array}{c}\text { Difference to average } \\
\mathrm{T}_{3} \text { and } \mathrm{T}_{4}(\%)+\end{array}$ \\
\hline Alanine & 10.1 & +0.45 \\
Arginine & 4.0 & -2.75 \\
Aspartic acid & 15.0 & +3.36 \\
Glutamic acid & 13.4 & +2.15 \\
Glycine & 10.0 & +1.45 \\
Histidine & 0.6 & -1.55 \\
Leucine & 7.6 & -0.55 \\
Isoleucine & 3.2 & -1.10 \\
Lysine & 4.9 & -2.50 \\
Methionine & 0.2 & -1.20 \\
Phenylalanine & 4.4 & +0.70 \\
Proline & 4.9 & +0.30 \\
Serine & 4.7 & +0.80 \\
Threonine & 7.7 & +1.55 \\
Tyrosine & $\overline{4.5}$ & +0.55 \\
Valine & 5.8 & -0.65 \\
Cystine & - & - \\
Tryptophan & - & - \\
\hline
\end{tabular}

* The values are expressed as per cent of recovered amino acids.

$+\mathrm{NP}-1 \mathrm{cl}(\%)$-average coli phage $\mathrm{T}_{3}$ and $\mathrm{T}_{4}(\%)$. $^{7.211}$

\section{Lysogeny}

Phage NP-1 formed a turbid plaque and UV-inactivated phage had no killing action on host bacteria (Table 8 ), The results indicate that the phage is lysogenic. Table 7 shows the frequency of lysogenization of phage NP-1 and NP-1 cl. The host bacteria were lysogenized with phage NP-1 at a frequency of about $3.5 \times 10^{-1}$ through various multiplicitics of infection. NP-1 cl could also lysogenze at a low frequency of $5 \times 10^{-3}$. As seen in Fig. 9, the lysogenic bacteria produced usually 


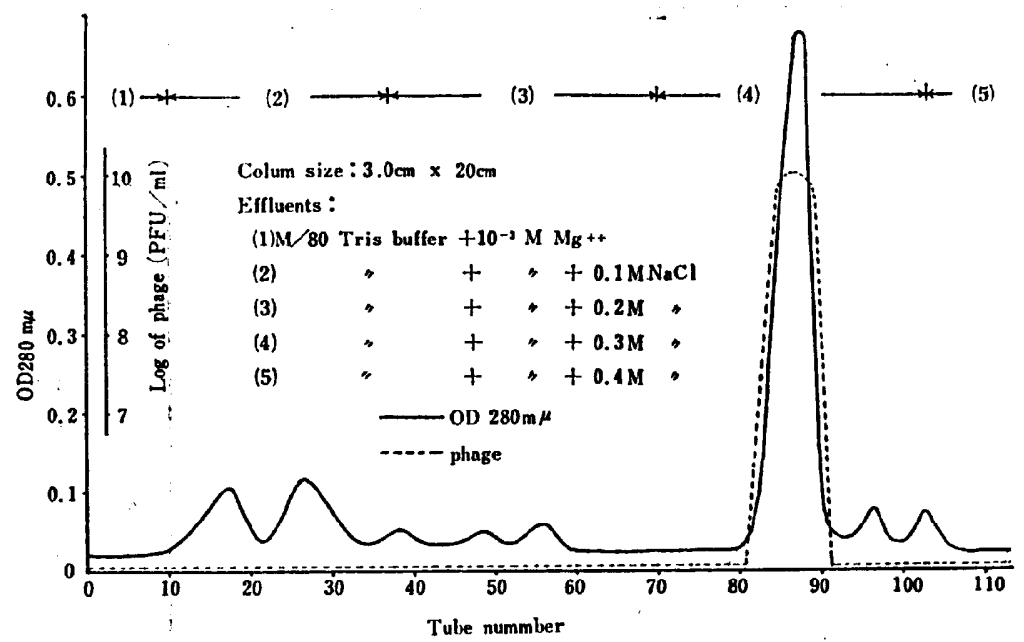

Fig. 8. Purification of phage NP-1cl by DEAE-cellulose column chromatography.

Table 7. Lysogenization of the bacteria with NP-1 and NP-1cl.

\begin{tabular}{ccc}
\hline Phage & Moi $^{*}$ & Frequency of lysogenization \\
\hline & 100 & $1.5 \times 10^{-1}$ \\
NP-1 & 10 & $3.5 \times 10^{-1}$ \\
& 3 & $3.5 \times 10^{-1}$ \\
NP-1 cl & 100 & $5.0 \times 10^{-3}$ \\
\hline
\end{tabular}

* Multiplicity of infection.

The frequency of lysogenization is represented as the number of lysogenic cells divided by the number of cells present at the time of infection.

Table 8. The determination of killing action of UV-inactivated phage on host bacteria.

\begin{tabular}{|c|c|c|c|c|c|}
\hline \multicolumn{3}{|c|}{ Inactivation of phage by UV irradiation } & \multicolumn{3}{|c|}{ Number of host bacteria } \\
\hline $\begin{array}{l}\text { UV dose } \\
\text { (sec) }\end{array}$ & $\begin{array}{c}\text { Phage } \\
(\mathrm{PFU} / \mathrm{ml})\end{array}$ & $\begin{array}{c}\text { Survivals } \\
(\mathscr{6})\end{array}$ & $\begin{array}{c}\text { Before } \\
\text { infection } \\
\text { (cells } / \mathrm{ml} \text { ) }\end{array}$ & $\begin{array}{c}\text { After } \\
\text { infection } \\
\text { (cells } / \mathrm{ml} \text { ) }\end{array}$ & $\begin{array}{c}\text { Killing rate } \\
(\mathscr{6})\end{array}$ \\
\hline 0 & $4.0 \times 10^{10}$ & 100 & $2.2 \times 10^{8}$ & $2.3 \times 10^{7}$ & 89.6 \\
\hline 50 & $3.5 \times 10^{9}$ & 8.8 & $2.2 \times 10^{8}$ & $6.9 \times 10^{7}$ & 58.7 \\
\hline 100 & $1.8 \times 10^{8}$ & 0.5 & $2.2 \times 10^{8}$ & $2.0 \times 10^{8}$ & 9.0 \\
\hline 150 & $1.0 \times 10^{6}$ & 0.003 & $2.2 \times 10^{8}$ & $2.1 \times 10^{8}$ & 4.5 \\
\hline
\end{tabular}

Phage NP-1 suspension $\left(4 \times 10^{10} \mathrm{PFU} / \mathrm{ml}\right)$ was irradiated by UV for the indicated times. To $1 \mathrm{ml}$ of the host culture $\left(2.2 \times 10^{\circ}\right.$ cells $\left./ \mathrm{ml}\right)$ was added $0.1 \mathrm{ml}$ of the UV-irradiated phage suspension; a ratio of phage particles/ bacterium was about 18 . The mixture was allowed to stand at $37^{\circ} \mathrm{C}$ for $10 \mathrm{~min}$ and plated after appropriate dilution, and the plates were incubated overnight to determine the survived cells. 


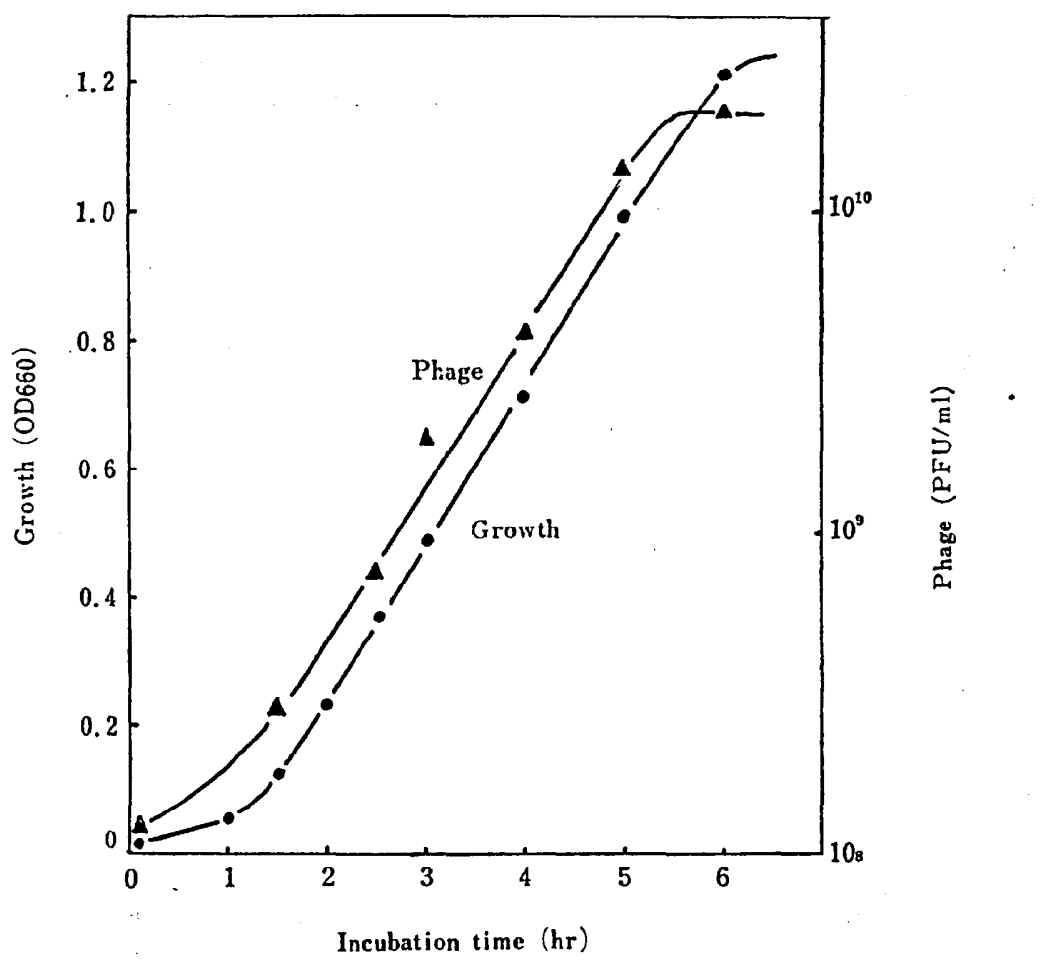

Fig. 9. Growth and phage production of a lysogenic strain.

high titers of about $10^{10} \mathrm{PFU} / \mathrm{ml}$ after 5 -hr incubation, suggesting that they were spontaneously lysed at a high frequency. The prolonged incubation of the lysogenic bacteria on slant-agar medium tended to decrease considerably in the phage production. However, when the lysogenic bacteria were successively transferred on new slant-agar medium within a week, the phage producibility was retained at a maximum level. In addition, the lysogenic bacteria at the logarithmic phase of growth were subject to anaerobic lysis. For instance, the 4hr culture grown in PY medium lysed within $1 \mathrm{hr}$ even by stopping to shake.

Takahashi ${ }^{28}$ and Bott et al." have found that temperate phages PBS1 and SP 10 can not perform a true lysogeny, since the spores which were derived from these lysogenic bacteria composed of each $50 \%$ of lysogenic and nonlysogenic one and the incubation of these lysogenic bacteria in the presence of antiphage serum decreased easily in the number of lysogenic cell. Spores from the bacteria lysogenized with NP1 could contain only a few per cent of lysogenic spores. These results 
suggest that this phage can not perform a true lysogeny such as $\lambda$ phage ${ }^{15)}$ and may belong to pseudolysogenic group as well as phage PBS 1 and SP 10. Unusual properties of this lysogenic bacteria will be investigated and described elsewhere.

\section{Failure of transduction with phage NP-1}

The transduction with NP-1 was studied by the same manner as described by Thorne, ${ }^{32}$ expect that minimum medium was supplimented with biotin, which was esential for the growth of strain No. 3. A few differnnt media were also used. As marker strains were used some leucine and arginine less mutants and several unknown mutants which were obtained by treatment with $\mathrm{N}$-methyl-N-nitroso guanidine. ${ }^{2)}$ So far examined, the transduction have not yet succeeded.

\section{Summary}

A bacteriophage of Bacillus natto was isolated and investigated on the following properties: host range, stability, adsorption kinetics, burst size, thermal inactivation, UV inactivation, DNA base composition, amino acid composition of whole phage, lysogeny and some other characteristics.

This phage was temperate and often produced a clear plaque mutant. The phage attacked against $B$. natto. The lysogenization frequency was $3.5 \times 10^{-1}$ and the burst size was about 50 . The phage was stable at the $\mathrm{pH}$ range between 5.0 to 9.0 , inactivated at $50^{\circ} \mathrm{C}$ and was very resistant to UV. The phage DNA did not contained an unusual base, and its guanine plus cytosine contents were about $41 \%$. Amino acid composition of whole phage protein was nearly similar to those as described with regard to $T$ series of coli phage. Attempt to transduce a few amino acid markers with phage was unsuccessfully made.

\section{Acknowledgment}

The authers are indebted to Prof. H. Fujii, Fukuoka Women's University for a gift of Bacillus natto strains and his helpful discussion, and thank Prof. Y. Ikeda, Tokyo University and Prof. K. Watanabe, Fukuoka University for supplying many other Bacillus strains. Thanks are also expressed to Prof. H. Endo for giving Escherichia coli strain B and coli phages, and Mr. K. Kurachi, for operating amino acid autoanalyzer. 


\section{References}

1) Adams, M. H., “Bacteriophage" Interscience Publishers, Inc., New York, 1959, p. 443.

2) Adelberg, E. A., M. Mandel, and G. C. C. Chen, Biochem. Biophys. Res. Comm., 18, 788 (1965).

3) Anfinsen, C. B., Fed. Proc., 20, 634 (1961).

4) Bott, K. and B. Strauss, Virology, 25, 212 (1965).

5) Brodetsky, A. B. and W. R. Romig, J. Bact., 90, 1655 (1965).

6) Burton, K., Biochem. J., 62, 315 (1956).

7) Fraser, D. and E. A. Jerrel, J. Biochem, 25, 29 (1953).

8) Fukuda, S., Nippon Nogeikagaku Kaishi, 29, 743 (1955).

9) Fujii, H., K. Oki, M. Makino, G. Akuno, and L. Takeya, ibid., 41, 39 (1967).

10) Harm. W., Z. Verebungsl., 94, 67 (1963).

11) Kallen, R. G., M. Simon, and J. Marmur, J. Mol. Biol., 5, 248 (1962).

12) Kinoshita, I. and T. Okumura, Nippon Nogeikagaku Kaishi, 29, 322 (1958).

13) Kitahara, K. and T. Kaneko, ibid., 32, 411 (1958).

14) Koch, G. and W. J. Dryer, Virology, 6, 291 (1958).

15) Lwoff, A., Bacteriol Rev., 17, 269 (1953).

16) Mahler, I., Biochem. Biophys. Res. Comm., 21, 384 (1965).

17) Mandel, J. D. and A. D. Hershey, Anal. Biochem., 1, 66 (1960).

18) Marmur, J. and P. Doty, J. Mol. Biol., 5, 109 (1963).

19) Murphy, J. S., Virology, 4, 563 (1958).

20) Okubo, O. and W. R. Romig, J. Mol. Biol., 14, 130 (1965).

21) Polsen, A. and R. W. G. Wyckoff, Science, 108, 501 (1948).

22) Ralston, D. J., B. Bear, M. Lieberman, and A. P. Krueger, J. Gen. Microbiol., 24, 313 (1961).

23) Romig, W. R. and A. M. Brodetsky, J. Bact., 82, 135 (1961).

24) Roscoe, D. H. and R. G. Tucker, Biochem. Biophys. Res. Comm., 16, 146 (1964).

25) Spizizen, I., Proc. Natl. Acad. Sci., 44, 1072 (1958),

26) Takagi, J., J. Gen. Appl. Microbiol., 8, 214 (1962).

27) Takahashi, I., Biochem. Biophys. Res. Comm., 5, 171 (1961).

28) Takahashi, I., J. Gen. Microbiol., 31, 211 (1963).

29) Takahashi, I. and J. Marmur, Biochem. Biophys. Res. Comm., 10, 289 (1963).

30) Takahashi, I. and J. Marmur, Nature, 197, 794 (1963).

31) Thorne, C. B., Fed. Proc., 20, 254 (1961).

32) Thorne, C. B., J. Bact., 83, 106 (1962).

33) Volkin, E. and E. W. Cohen, Methods of Biochemcal Analysis, 1958, Vol. 1, p. 287.

34) Watanabe, K. and K. Yamafuji, Enzymologia, 23, 353 (1961).

35) Wyatt, G. R., Biochem. J., 48, 584 (1951). 